\title{
Caavuranamide, a Novel Steroidal Alkaloid from the Ripe Fruits of Solanum caavurana Vell. (Solanaceae)
}

\author{
Nelissa Pacheco Vaz, ${ }^{a}$ Emmanoel V. Costa ${ }^{a, b}$ Érica L. Santos, ${ }^{a}$ Sandra Bos Mikich, ${ }^{c}$ \\ Francisco A. Marques, ${ }^{a}$ Raquel M. Braga, ${ }^{d}$ Camila Delarmelina, ${ }^{e}$ Marta C. T. Duarte, ${ }^{e}$ \\ Ana Lúcia T. G. Ruiz,f Vanessa H. S. Souza, João E. de Carvalho ${ }^{f}$ and \\ Beatriz H. L. N. Sales Maia ${ }^{*, a}$
}

a Departamento de Química, Universidade Federal do Paraná, Centro Politécnico, CP 19081, 81531-990 Curitiba-PR, Brazil

${ }^{b}$ Departamento de Química, Universidade Federal de Sergipe, Av. Marechal Rondon s/n, 49100-000 São Cristovão-SE, Brazil

'Laboratório de Ecologia, Embrapa Florestas, CP 319, 83411-000 Colombo-PR, Brazil

${ }^{d}$ Instituto de Química, Universidade Estadual de Campinas, CP 6154, 13083-970 Campinas-SP, Brazil

${ }^{e}$ Divisão de Microbiologia and ${ }^{f}$ Divisão de Farmacologia e Toxicologia, Centro Pluridisciplinar de Pesquisas Químicas Biológicas e Agrícolas (CPQBA), Universidade Estadual de Campinas, CP 6171, 13083-970 Campinas-SP, Brazil

\begin{abstract}
A investigação fitoquímica dos frutos maduros de Solanum caavurana Vell. (Solanaceae) forneceu um novo alcaloide esteroidal do tipo espirosolano, caavuranamida, juntamente com os alcaloides 4-tomatiden-3-ona e 5 $\alpha$-tomatidan-3-ona. Suas estruturas foram elucidadas através de métodos espectroscópicos. As atividades antiproliferativa e antimicrobiana para o extrato etanólico e subfrações provenientes de partição e de extração ácido-base foram investigadas. A caavuranamida apresentou atividade antibacteriana similar ao controle positivo cloranfenicol contra Rhodococcus equi.
\end{abstract}

Phytochemical investigation of the ripe fruits of Solanum caavurana Vell. (Solanaceae) afforded a novel steroidal alkaloid with spirosolane-type skeleton, named as caavuranamide, together with the alkaloids 4-tomatiden-3-one and 5 $\alpha$-tomatidan-3-one. Their structures were elucidated on the basis of spectroscopic methods. The antiproliferative and antimicrobial activities for the ethanolic extract, sub-fractions obtained from partition and acid-base treatment were also evaluated. Caavuranamide showed antibacterial activity similar to the chloramphenicol positive control against Rhodococcus equi.

Keywords: Solanum caavurana, Solanaceae, caavuranamide, steroidal alkaloids, spirosolane

\section{Introduction}

The genus Solanum is the most representative of Solanaceae family, comprising about 1400 species ${ }^{1}$ mainly distributed in tropical and subtropical regions of Americas, Africa and Australia. ${ }^{2}$ In Brazil, about 350 Solanum species have been identified, many of them endemic. ${ }^{3}$

Solanum caavurana Vell. grows as a bush or a small tree with $c a .5 \mathrm{~m} \mathrm{high}$, and is widely distributed in

*e-mail: noronha@ufpr.br
Brazil (in Ceará, Bahia, Mato Grosso do Sul, Paraná and Santa Catarina States), occurring in Paraguay and Argentina as well. It is popularly known as 'laranjinha do mato', 'jurubebarana' ${ }^{2}$ or 'jurubeba-branca', being used in folk medicine to treat anemia, liver disorders and as digestive as well. ${ }^{1}$ Although phytochemical studies on Solanum species resulted in the isolation of a great variety of steroidal alkaloids and glycoalkaloids, ${ }^{4,5}$ to the best of our knowledge, the only report found for this species was an unsuccessful search for solasodine in its unripe fruits. ${ }^{6}$ 
Here, we report the identification of a novel steroidal alkaloid, named as caavuranamide (1), along with the known 4-tomatiden-3-one (2) and 5 $\alpha$-tomatidan-3-one (3), isolated from the ethanolic extracts of the ripe fruits of Solanum caavurana Vell.

\section{Experimental}

\section{General experimental procedures}

Melting point (mp) was determined on a Quimis Q-340S23 micromelting point apparatus. IR spectra were acquired on a BIORAD FTS-3500, Fourier transform infrared (FTIR) equipment. Optical rotation was measured by using a Rudolph Research (Flanders, New Jersey) Autopol III automatic spectropolarimeter. Nuclear magnetic resonance (NMR) data were recorded at $293 \mathrm{~K}$ in $\mathrm{CDCl}_{3}$ on a Varian Inova 500 operating at $11.7 \mathrm{~T}$, observing ${ }^{1} \mathrm{H}$ at $500 \mathrm{MHz}$ and ${ }^{13} \mathrm{C}$ at $125 \mathrm{MHz}$. Chemical shifts $(\delta)$ are given in ppm relative to TMS (tetramethylsilane) $(\delta 0.00)$ as the internal standard. The electron spray ionization mass spectra (HRESIMS and HRESIMS/MS) were acquired in positive ion mode and recorded on a quadrupole-time of flight instrument (UltrOTOF-Q, Bruker Daltonics, Billerica, MA). The conditions were: capillary voltage of $3400 \mathrm{~V}$, dry gas temperature of $180{ }^{\circ} \mathrm{C}$, dry gas flow of $4 \mathrm{~L} \mathrm{~h}^{-1}$, nitrogen as nebulizer gas and $10 \mathrm{mmol} \mathrm{L}^{-1} \mathrm{NaTFA}$ (sodium trifluoroacetate) was used as the standard for internal and external calibration. For tandem mass spectrometry analysis (ESIMS/MS), nitrogen was used as the collision gas. Silica gel 60 (70-230 mesh) was used for column chromatography, aluminum precoated silica-gel plates $\left(60 \mathrm{~F}_{254}\right.$ Merck, $0.25 \mathrm{~mm}$ ) were used for analytical thin layer chromatography (TLC), and glass precoated silica-gel plates $\left(60 \mathrm{PF}_{254}\right.$ Merck, $1 \mathrm{~mm}$ ) were used for preparative TLC. The spots were detected by spraying with Dragendorff's or $p$-anisaldehyde reagents, followed by heating.

\section{Plant material}

The ripe fruits of $S$. caavurana were collected in the Parque Estadual de Vila Rica do Espírito SAnto (PEVR: $23^{\circ} 55^{\prime} \mathrm{S}$, $51^{\circ} 57^{\prime} \mathrm{W}$ ), in the municipal district of Fênix (Paraná State, Brazil), in January 2004. A voucher specimen (No. 28280) was deposited at the Herbarium of the Botany Department from Universidade Federal do Paraná (UPCB-UFPR).

\section{Extraction and isolation}

The ripe fruits of $S$. caavurana were dried at $40{ }^{\circ} \mathrm{C}$, crushed, pulverized $(180.5 \mathrm{~g})$ and successively extracted at room temperature with petrol $\left(30-60^{\circ} \mathrm{C}\right)(5$ days $)$ and ethanol (5 days), with the solvent removed every $24 \mathrm{~h}$. The ethanolic extract was submitted to liquid-liquid partition with $\mathrm{CH}_{2} \mathrm{Cl}_{2}$ followed by $n$-butanol ( $n$-but). Removal of the solvents under reduced pressure furnished 2.6 and $3.0 \mathrm{~g}$ of $\mathrm{CH}_{2} \mathrm{Cl}_{2}$ and $n$-but fractions, respectively, both revealing positive TLC Dragendorff's test. $\mathrm{CH}_{2} \mathrm{Cl}_{2}$ fraction was dissolved in $3 \%$ aqueous $\mathrm{HCl}$ and the acid liquid phase then extracted with $\mathrm{CHCl}_{3}(3 \times 20 \mathrm{~mL})$. The organic fractions were combined, dried with anhydrous $\mathrm{Na}_{2} \mathrm{SO}_{4}$ and concentrated under reduced pressure to obtain the neutral $\mathrm{CHCl}_{3}$ fraction $(947.0 \mathrm{mg})$. The remaining aqueous acid solution was adjusted to pH 10-12 with 37\% aqueous $\mathrm{NH}_{4} \mathrm{OH}$ followed by extraction with $\mathrm{CHCl}_{3}(3 \times 20 \mathrm{~mL})$. The resulting organic fractions were treated as previously described to yield an alkaloid residue $(122.5 \mathrm{mg}$ ), which was purified by preparative TLC eluted with EtOAc-MeOH 90:10 to yield $1(6.6 \mathrm{mg})$. The neutral $\mathrm{CHCl}_{3}$ fraction $(947.0 \mathrm{mg}$ ) was subjected to silica-gel column chromatography, with gradient elution of $\mathrm{CH}_{2} \mathrm{Cl}_{2} / \mathrm{EtOAc}$ from 100:0 to 25:75, EtOAc/MeOH from 100:0 to 90:10 and $\mathrm{MeOH}$, affording a total of 184 fractions (20 mL each), which were assembled in 18 subfractions according to their composition on TLC. Subfractions 10 $(34.2 \mathrm{mg})$ and $9(50.7 \mathrm{mg})$ were purified by preparative TLC eluted with $\mathrm{CH}_{2} \mathrm{Cl}_{2} / \mathrm{MeOH}$ 90:10 and $\mathrm{CH}_{2} \mathrm{Cl}_{2} / \mathrm{MeOH}$ 95:5, respectively, to yield $2(5.0 \mathrm{mg})$ and $\mathbf{3}(2.5 \mathrm{mg})$.

\section{Caavuranamide (1)}

Yellowish powder; ${ }^{1} \mathrm{H}$ and ${ }^{13} \mathrm{C}$ NMR data given in Table 1; mp 115-117 ${ }^{\circ} \mathrm{C} ;[\alpha]_{\mathrm{D}}^{25}+6.3\left(\mathrm{CHCl}_{3} ; c 0.0027\right) ; \mathrm{IR}(\mathrm{KBr})$ $v_{\text {max }} / \mathrm{cm}^{-1} 3429,2930,2852,2362,2341,1656,1543,1456$, 1383, 1264, 1037, 973, 872, 750 and 668; HRESIMS m/z $443.3705[\mathrm{M}+\mathrm{H}]^{+}$(calcd. for $\mathrm{C}_{28} \mathrm{H}_{46} \mathrm{~N}_{2} \mathrm{O}_{2}+\mathrm{H}^{+}, 443.6770$ ).

\section{4-Tomatiden-3-one (2)}

Light-yellow amorphous powder; ${ }^{1} \mathrm{H}$ and ${ }^{13} \mathrm{C}$ NMR data given in Table 1; HRESIMS $\mathrm{m} / z 412.3320[\mathrm{M}+\mathrm{H}]^{+}$(calcd. for $\mathrm{C}_{27} \mathrm{H}_{41} \mathrm{NO}_{2}+\mathrm{H}^{+}, 412.6338$ ).

\section{$5 \alpha$-Tomatidan-3-one (3)}

Yellow amorphous powder; ${ }^{1} \mathrm{H}$ and ${ }^{13} \mathrm{C}$ NMR data given in Table 1; HRESIMS $\mathrm{m} / \mathrm{z} 414.3443[\mathrm{M}+\mathrm{H}]^{+}$(calcd. for $\mathrm{C}_{27} \mathrm{H}_{43} \mathrm{NO}_{2}+\mathrm{H}^{+}$, 414.6496).

\section{In vitro antimicrobial activity}

The antimicrobial activity of the crude extracts and fractions were tested against nine microorganisms 
(Bacillus subtilis ATCC 6051, Escherichia coli ATCC 11775, Enterococcus faecium CCT 5079, Micrococcus luteus ATCC 4698, Pseudomonas aeruginosa ATCC 13388, Rhodococcus equi ATCC 25729, Staphylococcus aureus ATCC 6538, Salmonella choleraesuis ATCC 10708 and Staphylococcus epidermides ATCC 12228). Compound 1 was tested against E. coli, R. equi, S. aureus, S. epidermides and S. choleraesuis.

The bacteria strains were subcultured overnight at $36{ }^{\circ} \mathrm{C}$ in Nutrient Agar (Merck). Inoculum for the assays were prepared by diluting a scraped cell mass in $0.85 \%$ $\mathrm{NaCl}$ solution, adjusted to McFarland scale 0.5 and confirmed by spectrophotometer reading at $580 \mathrm{~nm}$. Cell suspensions were finally diluted to $10^{4} \mathrm{cfu} \mathrm{mL}^{-1}$ for use in the activity assays. Minimal inhibitory concentration (MIC) tests were carried out according to Eloff, ${ }^{7}$ using MüllerHinton broth on a tissue-culture test plate (96 wells). The stock solutions of crude extracts and fractions were diluted and transferred into the first well, and serial dilutions were made, so that concentrations in the range of 1.000-0.015 mg mL $\mathrm{mL}^{-1}$ were obtained. Chloramphenicol (Merck) was used as the reference antibiotic control in the range of $0.250-0.002 \mathrm{mg} \mathrm{mL}^{-1}$. The inoculum was added to all wells, and the plates were incubated at $36^{\circ} \mathrm{C}$ for $48 \mathrm{~h}$. Each concentration was screened in triplicate. Antimicrobial activity was detected by adding $20 \mu \mathrm{L}$ of $0.5 \%$ TTC (triphenyltetrazolium chloride, Merck) aqueous solution. MIC was defined as the lowest concentration of the sample that inhibited visible growth, as indicated by TTC staining (dead cells are not stained by TTC).

In vitro antiproliferative activity assay

Human tumor cell lines U251 (glioma, CNS), UACC-62 (melanoma), MCF-7 (breast), NCI-H460 (lung, non-small cells), OVCAR-03 (ovarian), HT-29 (colon), 786-0 (renal), NCI-ADR/RES (ovarian expressing phenotype multiple drugs resistance) and K562 (leukemia) were kindly provided by National Cancer Institute (NCI, U. S. Department of Health and Human Services). Stock cultures were grown in medium containing 5 mL RPMI 1640 (Gibco-BRL) supplemented with 5\% fetal bovine serum. Peniciline:streptomicine $\left(1000 \mu \mathrm{g} \mathrm{mL}^{-1}: 1000 \mathrm{UI} \mathrm{mL}^{-1}\right.$, $1 \mathrm{~mL} \mathrm{~L}^{-1}$ ) was added to experimental cultures. Cells in 96 well plates $(100 \mu \mathrm{L}$ cells per well) were exposed to sample concentrations in DMSO/RPMI $(0.25,2.5$, 25 and $250 \mu \mathrm{g} \mathrm{mL}^{-1}$ ) at $37{ }^{\circ} \mathrm{C}, 5 \%$ of $\mathrm{CO}_{2}$ in air for $48 \mathrm{~h}$. Final DMSO concentration did not affect cell viability. Afterwards, cells were fixed with $50 \%$ trichloroacetic acid and cell proliferation determined by spectrophotometric quantification $(540 \mathrm{~nm})$ of cellular protein content using sulforhodamine B assay. Using the concentration-response curve for each cell line, TGI (concentration that produces total growth inhibition or cytostatic effect) was determined through non-linear regression analysis using software ORIGIN 7.5 (OriginLab Corporation). ${ }^{8}$

\section{Results and Discussion}

The ethanolic extract from the ripe fruits of Solanum caavurana afforded steroidal alkaloids 1-3 (Figure 1).

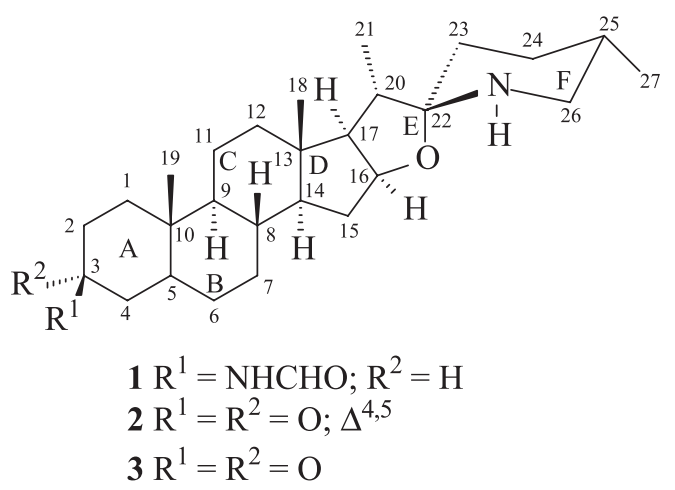

Figure 1. Chemical constituents isolated from the ripe fruits of Solanum caavurana.

Caavuranamide (1) was isolated as a yellowish powder and gave a positive Dragendorff reagent test. Its molecular formula $\mathrm{C}_{28} \mathrm{H}_{46} \mathrm{~N}_{2} \mathrm{O}_{2}$ was calculated from the HRESIMS quasi-molecular ion peak $[\mathrm{H}+\mathrm{H}]^{+}$at $m / z, 443.3705$. The HRESIMS/MS revealed two fragments at $m / z 255.2139$ and 300.2349 corresponding to a difference of $45.0210 \mathrm{Da}$, suggesting the loss of a formamide group ( $\mathrm{H}_{2} \mathrm{~N}-\mathrm{CHO}$, calcd. 45.041 Da).

The decoupled ${ }^{13} \mathrm{C}$ NMR spectrum of $\mathbf{1}$ (Table 1) displayed 28 carbon signals, mainly in the $\mathrm{sp}^{3} \mathrm{C}$ field characteristic of steroidal alkaloids, ${ }^{9}$ whereas DEPT-135 (distortionless enhancement by polarization transfer) analysis aided to attribute the presence of four methyl groups, one carbonyl ( $\left.\delta_{\mathrm{C}} 160.3\right)$, eleven methylenes, nine methines (including one oximethine) and three quaternary carbons.

The carbinolic hydrogen $\mathrm{H}-16\left(\delta_{\mathrm{H}} 4.14\right)$ was correlated with C-16 $\left(\delta_{\mathrm{C}} 78.5\right)$ in the HSQC (heteronuclear single quantum correlation) spectrum, that also showed four methyl hydrogens at $\delta_{\mathrm{H}} 0.82(\mathrm{~s}), 0.83(\mathrm{~s}), 0.86(\mathrm{~d}, J 6.5 \mathrm{~Hz})$ and $0.96(\mathrm{~d}, J 6.5 \mathrm{~Hz})$ correlated to carbons at $\delta_{\mathrm{C}} 16.9(\mathrm{C}-18)$, 11.4 (C-19), 19.3 (C-27) and 15.8 (C-21), respectively, possessing characteristic chemical shifts for steroidal alkaloid methyl groups. The signals at $\delta_{\mathrm{C}} 78.5$ (C-16), 99.3 (C-22) and 50.2 (C-26) supported a spirosolane-type structure. ${ }^{9}$ Through 2D NMR spectral data [HSQC, HMBC (heteronuclear multiple bond correlation) and NOESY (nuclear Overhauser effect spectroscopy)], the chemical 
Table 1. ${ }^{1} \mathrm{H}$ and ${ }^{13} \mathrm{C}$ NMR spectral data ${ }^{a}$ for compounds 1-3

\begin{tabular}{|c|c|c|c|c|c|c|}
\hline \multirow{2}{*}{ Position } & \multicolumn{2}{|r|}{1} & \multicolumn{2}{|r|}{2} & \multicolumn{2}{|r|}{3} \\
\hline & $\delta_{\mathrm{C}}$ & $\delta_{\mathrm{H}}(J \text { in } \mathrm{Hz})^{\mathrm{b}}$ & $\delta_{\mathrm{C}}$ & $\delta_{\mathrm{H}}(J \text { in } \mathrm{Hz})^{\mathrm{b}}$ & $\delta_{\mathrm{C}}$ & $\delta_{\mathrm{H}}(J \text { in } \mathrm{Hz})^{\mathrm{b}}$ \\
\hline 1 & 32.7 & $1.02(\mathrm{~m}), 1.72(\mathrm{~m})$ & 35.7 & $1.72(\mathrm{~m}), 2.02(\mathrm{~m})$ & 38.5 & $2.08(\mathrm{~m}), 1.38(\mathrm{~m})$ \\
\hline 2 & 32.1 & $1.68(\mathrm{~m}), 1.25(\mathrm{~m})$ & 33.9 & $2.41(\mathrm{~m}), 2.44(\mathrm{~m})$ & 38.1 & $2.11(\mathrm{~m}), 2.10(\mathrm{~m})$ \\
\hline 3 & 47.6 & $3.86(\mathrm{~m})$ & 199.6 & & 212.0 & \\
\hline 4 & 34.9 & $1.54(\mathrm{~m})$ & 123.9 & $5.74(\mathrm{~s})$ & 44.7 & $2.32(\mathrm{~m}), 2.29(\mathrm{~m})$ \\
\hline 5 & 45.3 & $1.18(\mathrm{~m})$ & 171.2 & & 46.7 & $1.55(\mathrm{~m})$ \\
\hline 6 & 28.2 & $1.21(\mathrm{~m})$ & 32.8 & $2.36(\mathrm{~m}), 2.07(\mathrm{~m})$ & 28.8 & $1.36(\mathrm{~m}), 1.21(\mathrm{~m})$ \\
\hline 7 & 32.0 & $1.68(\mathrm{~m}), 0.89(\mathrm{~m})$ & 32.2 & $1.83(\mathrm{~m}), 1.22(\mathrm{~m})$ & 32.7 & $2.07(\mathrm{~m}), 1.30(\mathrm{~m})$ \\
\hline 8 & 35.0 & $1.54(\mathrm{~m})$ & 35.1 & $1.73(\mathrm{~m})$ & 34.9 & $1.62(\mathrm{~m})$ \\
\hline 9 & 54.7 & $0.69(\mathrm{~m})$ & 53.8 & $1.05(\mathrm{~m})$ & 53.9 & $0.82(\mathrm{~m})$ \\
\hline 10 & 36.2 & & 38.7 & & 35.7 & \\
\hline 11 & 20.9 & $1.28(\mathrm{~m}), 1.54(\mathrm{~m})$ & 20.8 & $1.46(\mathrm{~m}), 1.54(\mathrm{~m})$ & 21.2 & $2.11(\mathrm{~m}), 1.57(\mathrm{~m})$ \\
\hline 12 & 40.2 & $1.13(\mathrm{~m}), 1.71(\mathrm{~m})$ & 39.8 & $1.16(\mathrm{~m}), 1.75(\mathrm{~m})$ & 40.1 & $1.17(\mathrm{~m}), 1.21(\mathrm{~m})$ \\
\hline 13 & 40.9 & & 40.7 & & 40.9 & \\
\hline 14 & 55.9 & $1.07(\mathrm{~m})$ & 55.1 & $1.09(\mathrm{~m})$ & 55.6 & $1.08(\mathrm{~m})$ \\
\hline 15 & 32.6 & $1.24(\mathrm{~m}), 2.00(\mathrm{~m})$ & 32.6 & $2.40(\mathrm{~m}), 2.43(\mathrm{~m})$ & 31.9 & $1.68(\mathrm{~m}), 1.21(\mathrm{~m})$ \\
\hline 16 & 78.5 & $4.14(\mathrm{~m})$ & 78.3 & $4.16(\mathrm{q}, 7.5)$ & 78.4 & $4.14(\mathrm{q}, 7.5)$ \\
\hline 17 & 62.0 & $1.60(\mathrm{~m})$ & 61.8 & $1.68(\mathrm{~m})$ & 61.9 & $1.55(\mathrm{~m})$ \\
\hline 18 & 16.9 & $0.82(\mathrm{~s})$ & 16.8 & $0.89(\mathrm{~s})$ & 16.9 & $0.86(\mathrm{~s})$ \\
\hline 19 & 11.4 & $0.83(\mathrm{~s})$ & 17.4 & $1.21(\mathrm{~s})$ & 11.5 & $1.04(\mathrm{~s})$ \\
\hline 20 & 42.9 & $1.66(\mathrm{~m})$ & 43.0 & $1.66(\mathrm{~m})$ & 43.0 & $1.74(\mathrm{~m})$ \\
\hline 21 & 15.8 & $0.96(\mathrm{~d}, 6.5)$ & 15.9 & $0.98(\mathrm{~d}, 6.5)$ & 15.9 & $0.98(\mathrm{~d}, 6.5)$ \\
\hline 22 & 99.3 & & 99.4 & & 99.1 & \\
\hline 23 & 26.6 & $1.66(\mathrm{~m}), 1.34(\mathrm{~m})$ & 26.6 & $1.67(\mathrm{~m}), 1.36(\mathrm{~m})$ & 26.6 & $1.66(\mathrm{~m}), 1.37(\mathrm{~m})$ \\
\hline 24 & 28.4 & $1.56(\mathrm{~m}), 1.37(\mathrm{~m})$ & 28.5 & $1.62(\mathrm{~m}), 1.33(\mathrm{~m})$ & 28.5 & $1.64(\mathrm{~m}), 1.34(\mathrm{~m})$ \\
\hline 25 & 30.9 & $1.60(\mathrm{~m})$ & 31.0 & $1.60(\mathrm{~m})$ & 31.0 & $1.61(\mathrm{~m})$ \\
\hline 26 & 50.2 & $2.74(\mathrm{~m})$ & 50.2 & $2.71(\mathrm{~m}), 2.75(\mathrm{~m})$ & 50.2 & $2.73(\mathrm{~m}), 2.76(\mathrm{~m})$ \\
\hline 27 & 19.3 & $0.86(\mathrm{~d}, 6.5)$ & 19.3 & $0.88(\mathrm{~d}, 6.5)$ & 19.3 & $0.87(\mathrm{~d}, 6.5)$ \\
\hline $\mathrm{C} \underline{\mathrm{HO}}$ & 160.3 & $8.12(\mathrm{~m})$ & & & & \\
\hline $\mathrm{NHCHO}$ & & $5.36(\mathrm{~d}, 7.5)$ & & & & \\
\hline
\end{tabular}

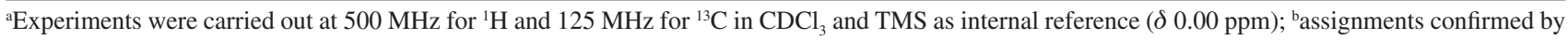
DEPT-135, HSQC, HMBC and NOESY experiments.

shifts of all hydrogens, as well as its correlations, were fully established (Table 1).

The ${ }^{1} \mathrm{H}$ NMR spectrum revealed a signal at $\delta_{\mathrm{H}} 8.12$ $(\mathrm{m}, 1 \mathrm{H})$ that was assigned to the formyl hydrogen of the formamide group, which existence was previously evidenced by HRESIMS analysis, in association with the presence of a downfield carbonyl group at $\delta_{\mathrm{C}} 160.3$. The existence of a hydrogen at $\delta_{\mathrm{H}} 3.86$ and the remaining broad low field signal at $\delta_{\mathrm{H}} 5.36(\mathrm{~d}, 1 \mathrm{H}, J 7.5 \mathrm{~Hz})$ were assigned to H-3 and the formamide $N$-hydrogen, respectively, by analogy with solanopubamide A. ${ }^{10}$

The NOESY spectrum was used to confirm the proposed stereochemistry assignments made for caavuranamide $\mathbf{1}$ (Figure 2), as the trans junction of $\mathrm{A} / \mathrm{B}$ ring and cis junction of $\mathrm{D} / \mathrm{E}$ ring, as well as $(25 S)-22 \beta N$-spirosolane configuration (as observed for tomatidine) ${ }^{9}$ and the orientation of $3 \beta-N$-formylamino group. A strong NOE (nuclear Overhauser effect) was observed between the

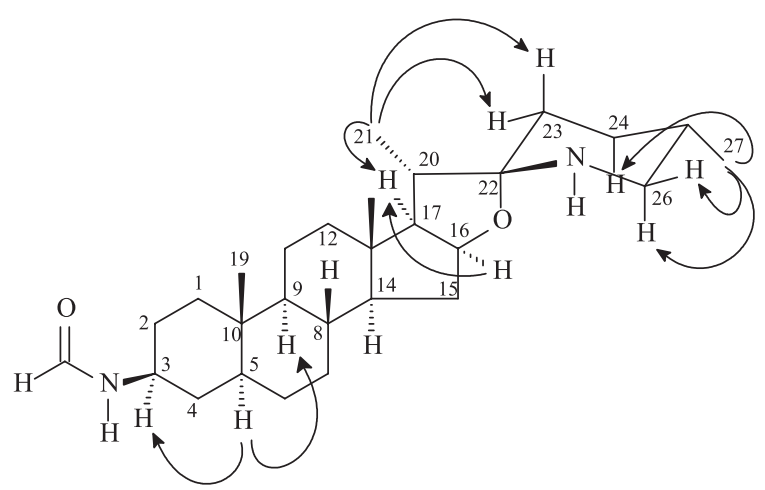

Figure 2. Relevant NOESY correlations observed for caavuranamide (1).

signal of $\mathrm{CH}_{3}-27\left(\delta_{\mathrm{H}} 0.86\right)$ with the signal of $\mathrm{H}-26\left(\delta_{\mathrm{H}}\right.$ 2.74) and $\mathrm{H}-24_{\mathrm{ax}}\left(\delta_{\mathrm{H}} 1.37\right)$, indicating that $\mathrm{CH}_{3}-27$ is in equatorial position. Strong correlations could also be observed among $\mathrm{C}_{3}-21\left(\delta_{\mathrm{H}} 0.96\right)$ with $\mathrm{H}-17\left(\delta_{\mathrm{H}} 1.60\right)$, $\mathrm{H}-23\left(\delta_{\mathrm{H}} 1.66\right.$ and 1.34$)$ and $\mathrm{H}-16\left(\delta_{\mathrm{H}} 4.14\right)$, suggesting 
a $S$ configuration for $\mathrm{C}-22$ and the cis junction of the $\mathrm{D} / \mathrm{E}$ ring. The axial orientation of $\mathrm{H}-5\left(\delta_{\mathrm{H}} 1.18\right)$ was sustained by intense correlations with $\mathrm{H}-9_{\mathrm{ax}}\left(\delta_{\mathrm{H}} 0.69\right)$ and $\mathrm{H}-3_{\mathrm{ax}}$ $\left(\delta_{\mathrm{H}} 3.86\right)$. This later information denotes that the substituent $\mathrm{N}$-formylamino located in C-3 is found in $3 \beta$ arrangement. The above findings supported the configuration $(25 S, 22 S)$ $3 \beta-N$-formylamino- $5 \alpha$-spirostane which is in agreement with solanopubamide $\mathrm{A}^{10}$ and with data reported for

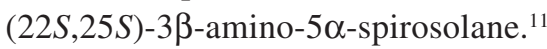

It is known that steroidal alkaloids isolated from the Solanaceae possess almost exclusively a 3 -hydroxyl substituent or its glycosylated derivatives. The only report of a $N$-formyl steroidal alkaloid in the Solanum ${ }^{10}$ genus indicated a solanidane-type skeleton. Caavuranamide [(22S,25S)-3 $\beta-N$-formylamino- $5 \alpha$-spirosolane] (1) is the second report of a $N$-formyl steroidal alkaloid in this genus, and the first with a spirosolane-type skeleton.

Compounds $\mathbf{2}$ and $\mathbf{3}$ were identified on the basis of ${ }^{1} \mathrm{H}$ and ${ }^{13} \mathrm{C}$ NMR spectral data (Table 1) as 4-tomatiden3 -one and 5 $\alpha$-tomatidan-3-one, respectively. Although substance 2 has been obtained before by microbial ${ }^{12}$ conversion of tomatidine, this is the first report of its isolation directly from plants. Compound $\mathbf{3}$ was previously isolated ${ }^{13}$ from the roots of a hybrid plant between Lycopersicon esculentum Mill. and L. hirsutum Humb. et Bonpl. (Solanaceae). The ${ }^{1} \mathrm{H}$ and ${ }^{13} \mathrm{C}$ NMR data, as well as the assignments of chemical shifts for both compounds, were incomplete in the literature, and are now supported by DEPT-135 and HSQC experiments.

The crude extracts and fractions obtained from acid-base treatment were evaluated for antimicrobial (Table 2) and in vitro antiproliferative activities (Table 3 ). According to Table 2, the ethanolic extracts do not show significant activity for neither of tested microorganisms, whereas $\mathrm{CH}_{2} \mathrm{Cl}_{2}$ and $n$-but extracts, as well as those subfractions obtained from acid-base treatment, showed potent activity for E. coli, M. luteus, R. equi, B. subtilis and E. faecium, being similar and even in some cases, stronger than positive control chloramphenicol. Compound $\mathbf{1}(6.6 \mathrm{mg})$ exhibited activity (MIC $135 \mu \mathrm{mol} \mathrm{L}^{-1}$ ) similar to chloramphenicol

Table 2. Antibacterial activity of extracts, fractions and compound $\mathbf{1}$ of ripe fruits of S. caavurana

\begin{tabular}{|c|c|c|c|c|c|c|c|c|c|}
\hline \multirow{3}{*}{ Extract and fractions } & \multicolumn{9}{|c|}{$\mathrm{MIC} /\left(\mu \mathrm{g} \mathrm{mL}^{-1}\right)$} \\
\hline & \multicolumn{9}{|c|}{ Microorganisms } \\
\hline & B. subtilis & E. coli & E. faecium & M. luteus & P. aeruginosa & R. equi & S. aureus & S. choleraesuis & S. epidermides \\
\hline EtOH extract & b & b & b & b & b & 500 & b & 700 & $\mathrm{~b}$ \\
\hline $\mathrm{CH}_{2} \mathrm{Cl}_{2}$ fraction & 125 & 125 & 125 & 60 & $\mathrm{~b}$ & 60 & 700 & 600 & 300 \\
\hline$n$-But fraction & 125 & 60 & 125 & 60 & $\mathrm{~b}$ & 60 & 500 & 400 & 250 \\
\hline Neutral $\mathrm{CHCl}_{3}$ fraction & 30 & 60 & 60 & 60 & b & 60 & 600 & 400 & 300 \\
\hline Alkaloid residue & 60 & 60 & 60 & 60 & $\mathrm{~b}$ & 30 & 600 & 200 & 250 \\
\hline Compounds & \multicolumn{9}{|c|}{$\mathrm{MIC} /(\mu \mathrm{mol} \mathrm{L}-1)$} \\
\hline Caavuranamide (1) & a & b & a & a & a & 135 & 1580 & b & $\mathrm{b}$ \\
\hline Chloramphenicol $^{\mathrm{c}}$ & 62 & 124 & 217 & 155 & 2630 & 124 & 62 & 186 & 0.124 \\
\hline
\end{tabular}

${ }^{a}$ Not tested; ${ }^{\mathrm{b}}$ concentration $>1000 \mu \mathrm{g} \mathrm{mL}{ }^{-1}$; ${ }^{\mathrm{c}}$ positive control for bacteria.

Table 3. Antiproliferative activity of extracts and fractions of ripe fruits of $S$. caavurana against cancer cell lines

\begin{tabular}{lcccccccccc}
\hline & \multicolumn{10}{c}{ TGI / $\left.(\mu \mathrm{g} \mathrm{mL})^{-1}\right)$} \\
\cline { 2 - 11 } Extracts and fractions & \multicolumn{10}{c}{ Tumor cell lines } \\
\cline { 2 - 12 } & U251 & UACC-62 & MCF-7 & NCI-H460 & OVCAR-3 & HT-29 & $786-0$ & K562 & NCI-ADR/RES & VERO \\
\hline & b & 2.11 & 93.06 & b & 84.49 & 60.90 & 60.62 & b & 102.13 & b \\
$\mathrm{CH}_{2} \mathrm{Cl}_{2}$ fraction & 75.53 & b & 142.48 & b & 139.66 & 115.39 & 94.97 & b & $b$ & b \\
$n$-But fraction & 82.45 & b & 100.40 & b & 117.84 & 62.13 & 46.04 & b & 243.35 & b \\
Neutral $\mathrm{CHCl}_{3}$ fraction & 90.47 & 8.09 & 57.17 & 100.27 & 100.27 & 73.67 & 80.63 & b & 82.37 & b \\
Alkaloid residue & 65.59 & 37.14 & 98.21 & b & 51.77 & 228.07 & 74.64 & b & 61.20 & b \\
Doxorubicin & 3.24 & 0.15 & 10.49 & $>25$ & 5.62 & $>25$ & 3.73 & $>25$ & $>25$ & $>25$ \\
\hline
\end{tabular}

aPositive control; ${ }^{\mathrm{b}}$ concentration $>250 \mathrm{mg} \mathrm{mL}^{-1}$; U251 (glioma CNS), UACC-62 (melanoma), MCF-7 (breast), NCI-H460 (lung, non-small cells), OVCAR-3 (ovarian), HT-29 (colon), 786-0 (renal), K562 (leukemia), NCI-ADR/RES (ovarian expressing phenotype multiple drugs resistance) and VERO (renal, normal cells, green monkey); TGI: concentration $\left(\mu \mathrm{g} \mathrm{mL}^{-1}\right)$ total growth inhibition. 
(MIC $124 \mu \mathrm{mol} \mathrm{L}^{-1}$ ) for $R$. equi, but it is less active than the alkaloid residue that furnished $\mathbf{1}$.

For in vitro antiproliferative activity, the extracts and respective subfractions showed to be active for a wide range of human tumor cell lines, with the ethanolic extract and neutral $\mathrm{CHCl}_{3}$ fraction presenting the strongest antiproliferative results for melanoma (UACC-62) with TGI values of 2.11 and $8.09 \mu \mathrm{g} \mathrm{mL}{ }^{-1}$, respectively.

\section{Conclusions}

The present phytochemical investigation of the ripe fruits of $S$. caavurana Vell. afforded a novel steroidal alkaloid with spirosolane-type skeleton, named as caavuranamide (1), together with the alkaloids 4-tomatiden3 -one (2) and 5- $\alpha$-tomatidan-3-one (3). Compound (1) showed significant antibacterial activity (MIC $135 \mathrm{~mol} \mathrm{~L}^{-1}$ ) for R. equi, similar to chloramphenicol (MIC $124 \mathrm{~mol} \mathrm{~L}^{-1}$ ).

\section{Supplementary Information}

Supplementary information (Figure S1-S20) is available free of charge at http://jbcs.sbq.org.br as PDF file.

\section{Acknowledgements}

The authors are grateful to Prof. Dr. Norberto P. Lopes of the Faculdade de Ciências Farmacêuticas de Ribeirão Preto, USP (Ribeirão Preto-SP, Brazil) for the HRESIMS and HRESIMS/MS analysis, and to Coordenação de Aperfeiçoamento de Pessoal de Nível Superior (CAPESPROCAD) and the Fundação Araucária (Paraná, Brazil), for financial support. F. A. M. is also grateful to Conselho Nacional de Desenvolvimento Científico e Tecnológico (CNPq-INCT). J. E. C. is grateful to CNPq for research fellowship. N. P. V. is grateful to CAPES for scholarship. S. B. M. receives a Productivity Fellowship (process No. 308419/2008-1) from CNPq.

\section{References}

1. Nurit-Silva, K.; Agra, M. F.; Lat. Am. J. Pharm. 2009, 28, 675.

2. Mentz, L. A.; Oliveira, P. L.; Pesquisas, Botânica 2004, $54,53$.

3. Silva, T. M. S.; Camara, C. A.; Freire, K. R. L.; Silva, T. G.; Agra, M. F.; Bhattacharyya, J.; J. Braz. Chem. Soc. 2008, 19, 1048.

4. Lu, Y.; Luo, J.; Kong, L.; Phytochemistry 2011, 72, 668.

5. Colmenares, A. P.; Rojas, L. B.; Usubillaga, A.; Bol. Latinoam. Caribe Plantas Med. Aromat. 2010, 9, 80.

6. Barbosa-Filho, J. M.; Agra, M. F.; Oliveira, R. A. G.; Paulo, M. Q.; Trolin, G.; Cunha, E. V. L.; Ataíde, J. R.; Bhattacharrya, J.; Mem. Inst. Oswaldo Cruz 1991, 86, 189.

7. Eloff, J. N.; Planta Med. 1998, 64, 711.

8. Shoemaker, R. H.; Nat. Rev. Cancer 2006, 6, 813.

9. Radeglia, R.; Adam, G.; Ripperger, H.; Tetrahedron Lett. 1977, $11,903$.

10. Kumari, G. N. K.; Rao, L. J. M.; Rao, K. V. R.; Rao, N. S. P.; Kaneko, K.; Mitsuhashi, H.; Phytochemistry 1986, 25, 2003.

11. Maxwell, A.; Pingal, R.; Reynolds, W. F.; McLean, S.; Phytochemistry 1996, 43, 913.

12. Belič, I.; Garberc-Porekar, V.; Sočič, H.; Žakelj, M.; Z. Allg. Mikrobiol. 1982, 22, 359.

13. Nagaoka, T.; Yoshihara, T.; Ohra, J.; Sakamura, S.; Phytochemistry 1993, 34, 1153.

Submitted: May 16, 2011

Published online: December 13, 2011

FAPESP has sponsored the publication of this article. 